\title{
INTEGRASI PENDIDIKAN DAN IMPLIKASINYA TERHADAP LEMBAGA PENDIDIKAN DI INDONESIA
}

\author{
Rusdiyanto \\ Dosen Unlversitas Muhammadiyah Jember \\ rusdi.um.jember@gmail.com
}

\begin{abstract}
Abstrak
Wacana Integrasi di Indonesia sudah lama digaungkan sebagaimana yang tertuang dalam UUSPN Nomor 20 Tahun 2003 pasal 30 yang mewajibkan penyelenggaraan pendidikan Agama pada semua strata pendidikan sebagai bentuk kesadaran bersama untuk mencapai kualitas hidup yang utuh. Pelaksanaan pendidikan memiliki dua misi utama yaitu pembinaan daya intelektual dan pembinaan daya moral, Mensinergikan sains dan Islam (Agama) merupakan sesuatu yang sangat penting, bahkan keharusan, karena dengan mengabaikan nilai-nilai Agama dalam perkembangan sains dan tekhnologi akan melahirkan dampak negatif yang luar biasa. Dampak negatif dari kecendurungan mengabaikan nilai-nilai (moral Agama) bisa kita lihat secara emperik pada perilaku korup dan lain sebagaianya yang dilakukan oleh manusia dimuka bumi ini dengan munggunakan kekuatan sains dan tekhnolog. Fokus Pembahasan: Apa Pengertian Integrasi Pendidikan dan Bagaimana Implikasinya terhadap lembaga Pendidikan di Indonesia.
\end{abstract}

Keywords: Integrasi, Pendidikan Islam

\section{Pendahuluan}

Wacana Integrasi di Indonesia sudah lama digaungkan sebagaimana yang tertuang dalam UUSPN Nomor 20 Tahun 2003 pasal 30 yang mewajibkan penyelenggaraan pendidikan Agama pada semua strata pendidikan sebagai bentuk kesadaran bersama untuk mencapai kualitas hidup yang utuh. ${ }^{1}$

1 Ahmad Barizi, Pendidikan Integratif Akar Tradisi dan Integrasi Keilmuan Pendidikan Islam, (Malang: UIN Maliki Press, 2011), hlm. 256. 
Kementerian Pendidikan dan Kebudayaan akan merubah kurikulum pendidikan 2013. Perubahan yang paling berdasar adalah nantinya pendidikan akan berbasis science dan tidak berbasis hafalan lagi. Menurut Mendikbud M Nuh di kantor wapres JI Veteran, Jakarta, Selasa (13/11/2012) disampaikan "Yang paling esensial dari 2013 yang kita rancang, untuk SD itu pendekatan yang kita gunakan semua berbasis science, anak dikenalkan, mulai melihat memperhatikan bertanya, observasi, sehingga tidak lagi diorientasikan kepada hafalan-hafalan," kemudian untuk pendekatan pembelajaran tematik integratif, jumlah pelajaran bisa di kurangi dari 10 menjadi 6 mata pelajaran. Namun, jumlah waktunya akan ditambah, sedikitnya menjadi 4 jam dalam seminggu. ${ }^{2}$

Sementara, dalam pelaksanaan pendidikan memiliki dua misi utama yaitu pembinaan daya intelektual dan pembinaan daya moral, Mensinergikan sains dan Islam (Agama) merupakan sesuatu yang sangat penting, bahkan keharusan, karena dengan mengabaikan nilai-nilai Agama dalam perkembangan sains dan tekhnologi akan melahirkan dampak negatif yang luar biasa. Dampak negatif dari kecendurungan mengabaikan nilai-nilai (moral Agama) bisa kita lihat secara emperik pada perilaku korup dan lain sebagaianya yang dilakukan oleh manusia dimuka bumi ini dengan munggunakan kekuatan sains dan tekhnologi. ${ }^{3}$ Adapun fokus isi dan pembatasan pembahasan terkait: (1) Pengertian Intrgrasi dalam pendidikan, (2) Integrasi Pendidikan Islam terhadap Lembaga Pendidikan Islam di Indonesia.

\section{Pengertian Integrasi Pendidikan}

Integrasi memiliki arti penggabungan / pembauran hingga menjadi satu kesatuan yang utuh. ${ }^{4}$ Tipologi hubungan antara sains dan agama menurut lan. G. Barbour, sebagai tokoh pengkaji hubungan sains dan agama telah memetakan hubungan antara keduanya. Pandangan ini memunculkan hubungan yang lebih bersahabat dari pandangan yang terdahulu. Yakni, doktrin yang dimiliki sains dan agama sama-sama dianggap valid dan menjadi sumber koheren dalam pandangan dunia. Bahkan, pemahaman tentang dunia yang diperoleh melalui sains diharapkan dapat memperkaya

2 Enam mata pelajaran itu adalah Bahasa Indonesia, PPKN, Matematika, Agama, Seni Budaya dan Pendidikan Jasmani. Nuh menjelaskan pendekatan pembelajaran tematik integratif contohnya Guru Bahasa Indonesia bisa juga menjelaskan tentang fenomena alam dalam pelajaran IPA.

${ }^{3}$ Tim Penyusun Buku, Memadu Sains dan Agama menuju Menuju Universitas Islam Masa Depan, (Malang: Bayumedia, 2004), hlm. xi-xii.

${ }^{4}$ M. Dahlan Dkk, Kamus Induk Istilah IImiah Seri Intelektual (Surabaya; Target Press, 2003), hlm. 322. 
pemahaman keagamaan bagi orang yang beriman. Terdapat tiga versi pemahaman tentang integrasi, yakni:

1. Natural Theology; Mengklaim bahwa eksistensi Tuhan dapat disimpulkan dari bukti tentang desain alam, yang dengan keajaiban struktur alam membuat manusia semakin menyadari dan meyakini alam ini sebagai karya Allah swt.

2. Theology of Natural; Pada pandangan ini, terdapat klaim bahwa sumber utama teologi bersumber diluar sains, namun pendangan ini juga berpendapat bahwa doktrin tradisional harus tetap dirumuskan ulang dalam pandangan sanis terkini.

3. Sintesis Sistematis; Merupakan cara pandang dalam hubungan antara sains dan Agama dengan hubungan yang lebih sistematis dapat dilakukan jika sains dan agama memberikan kontribusi kearah pandangan dunia yang lebih koheren yang dielaborasi dalam kerangka metafisika yang komprehensif. ${ }^{5}$

\section{Implikaasi Integrasi terhadap Lembaga Pendidikan di Indonesia}

Gagasan dan upaya untuk mewujudkan kebijakan pendidikan nasional yang terintegrasi dengan meniadakan dualisme sistem pendidikan telah mulai muncul sejak awal kemerdekaan Indonesia, dimana pemerintah mulai menyiapkan rancangan kebijakan pendidikan nasional dalm bentuk undangundang sistem pedidikan.

Undang-undang sistem pendidikan nasional yang pertama ditetapkan setelah Indonesia merdeka, yaitu Undang-Undang No. 4 Tahun 1950 (tentang Dasar-Dasar Pendidikan dan Pengajaran di Sekolah) sesungguhnya mulai mengakui keberadaan dari lembaga pendidikan islam, yaitu bahwa mereka yang mengikuti pendidikan di lembaga pendidikan Islam yang telah diakui oleh Menteri Agama (pemerintah) di pandang telah menyelesaikan wajib belajar.

Dengan adanya undang-undang sistem pendidikan nasional yang pertama tersebut merupakan jembatan dalam melakukan intergrasi pendidikan agama dan umum dalam sistem pendidikan nasional. Disamping itu, undang-undang tersebut juga mengatur tentang penyelenggaraan pendidikan agama disekolah umum negeri, serta keterlibatan pemerintah dalam upaya penyediaan dan pembinaan guru agama yang mengajarkan mata pelajaran agama.

Dalam upaya mengintegrasikan sistem pendidikan nasional Pada tahun 1974, pemerintah mengeluarkan Keputusan Presiden No. 34 Tahun 1972

${ }^{5}$ Ian. G. Barbour, Juru Bicara Tuhan Antara Sains dan Agama, Terj. E.R. Muhammad (Bandung; Mizan, 2004), hlm. 83-84. 
tentang kewenangan penyelenggaraan pendidikan yang dilakukan di bawah satu pintu, yaitu oleh Departemen Pendidikan dan Kebudayaan, termasuk di dalamnya penyelenggaraan pendidikan agama. Keputusan itu diikuti oleh Inpres No. 15 Tahun 1974 tentang Pelaksanaan Keputusan Presiden tersebut.

Mengenai kedua kebijakan pemerintahan tersebut Nurhayati Djamas menjelaskan bahwa pada mulanya mendapat tantangan keras dari kalangan pendukung pendidikan Islam. Namun berdasarkan hasil keputusan pertemuan MP3AI yang disampaikan kepada presiden melalui menteri agama, akhirnya diputuskan kompromi dengan dikeluarkannya SKB tiga Menteri ( $P$ \& K, Dalam Negeri, dan Menteri Agama) yang menetapkan ketentuan tentang kurikulum madrasah yang menyeimbangkan antara kurikulum umum dengan kurikulum agama $(70 \%: 30 \%){ }^{6}$

Implementasi kebijakan tersebut di lingkungan madrasah menandai langkah awal bagi terciptanya integrasi pendidikan Islam di madrasah dengan sekolah umum, hal ini mengisyaratkan bahwa lulusan madrasah dapat melanjutkan pendidikan ke tingkat yang lebih tinggi di sekolah umum karena dengan adanya kebijakan tersebut maka kedudukan madrasah disamakan dengan sekolah umum.

Selanjutnya dalam upaya melakukan pengintegrasian diantara pendidikan agama dan umum, maka pada tahun 1989 dikeluarkan UndangUndang Sistem Pendidikan Nasional yang baru sebagai penggati UU No. 14 Tahun 1954. Undang-Undang tersebut menempatkan posisi madrasah pada pada semua jenjang sebagai sekolah umum yang bercirikan Islam dengan ketetapan pelaksanaan kurikulum pendidikan nasional di lingkungan madarasah.

Selanjutnya kebijakan pemerintah yang mutakhir dalam upaya pengintegrasian pendidikan umum dan agama adalah Undang-Undang Nomor 20 Tahun 2003 Tentang Sistem Pendidikan Nasional, yang UndangUndang tersebut mengakomodasi prinsip otonomi daerah dan mengantisipasi persaingan global.

Salah satu prinsip yang mendasar dari prinsip otonomi yang diakomodasi adalah adanya pengakuan terhadap otonomi sekolah, di samping penghapusan diskriminasi antara pendidikan yang dikelola pemerintah dan pendidikan yang dikelola masyarakat serta pembedaaan antara pendidikan keagamaan dan pendidikan umum. Karena ini karena adanya tuntutan untuk diterapkannya prinsip demokrasi, desentralisasi,

${ }^{6}$ Haidar, Mengenai ordonansi guru Baca juga Nurhayati Jamas, Dinamika Pendidikan Islam di Indonesia Pasca Kemerdekaan (Jakarta : Rajawali Pers, 2008), hlm. 7. 
keadilan dan menjunjung tinggi hak asasi manusia dalam berbangsa dan bernegara.

Selain itu dengan adanya Peraturan Pemerintah No. 19 tahun 2005 tentang Standar Nasional Pendidikan yang merupakan penjabaran lebih lanjut dari amanat UU Sisdiknas No. 20 tahun 2003 tersebut, dalam pasal 1 ayat 1 dijelaskan bahwa standar nasional pendidikan adalah kriteria minimal tentang sistem pendidikan di seluruh wilayah hukum Negara Kesatuan Republik Indonesia. Hal tersebut adalah untuk menjembatani mutu pendidikan nasional dalam rangka mencerdaskan kehidupan bangsa dan membentuk watak serta peradaban bangsa yang bermartabat.

Undang-undang dan peraturan pemerintah tersebut telah memberi peluang yang sama untuk mendapat pengakuan, penghargaan dan tidak ada diskriminasi di mata negara, sehingga diharapkan dapat menjembatani dualisme dan dikotomi dalam sistem pendidikan nasional di Indonesia. ${ }^{7}$

\section{Integrasi Pendidikan di SMA Nurul Jadid Probolinggo}

Pendidikan yang berbasis integral seperti Nurul Jadid yang keberadaannya menjadi hal yang akan membuat perubahan disaat adanya korelasi dan konfirmasi dengan sosial kuktur peserta didik atau santri hidup. Sejauh ini lembaga berekspansi kedunia komunikasi dan informasi dengan adanya Radio SMANJA yang bekerja sama dengan radio BBC Australia, diharapkan siwa-siswi jurusan bahasa mampu berkiprah dalam dunia komunikasi dan informasi. Kegiatan tersebut diprioritaskan untuk kebutuhan dakwah islam dan hiburan para santri. Pihak Australia setiap bulannya memantau perkembangannya dan mengirimkan CD langsung dari Australia guna perkembangan baru dunia komunikasi dan informasi di SMA Nurul Jadid.

Sejak tahun 2006 SMA Nurul Jadid bekerjasama dengan Bank Muamalat dengan tujuan untuk menanamkan kepada peserta didik mereka mempunyai pengetahuan dibidang perbankan/perekonomian syari'at islam. Ini merupakan eksperimen program IPS yang melengkapi keberadaan laboratorium (Bank Mini) mereka dalam mempraktikkan Akuntansi Perbankan, terutama yang berbasis syari'ah islam. ${ }^{8}$

7"Integrasi Pendidikan Agama dan Umum" diakses dari http://www.anekamakalah.com/ diakses tanggal 16 Januari 2018 pada pukul 20.10

${ }^{8}$ Wawanara dengan Safitri Yuliana, alumni SMA Nurul Jadid tahun 2012. (Diakses Tanggal 1 Maret 2017). Penyelenggaraan Bank Mini yang ada dikawasan P.P Nurul Jadid menjadi laboratorium sementara siswa-siswi terbagi menjadi beberapa kelompok agar dapat membagi waktu praktiknya yang sudah berlangsung sejak tahun 2006. 
Dalam pemberian pelajaran yang sifatnya satu arah (monolog) tidak mampu menghasilkan out put yang siap mandiri. Untuk itu pendidik hendaknya memberikan kesempatan dan dorongan kepada peserta didik agar senantiasa aktif dan menjalankan segala aktifitas tanpa dibebani perasaan takut berbuat kesalahan. Perserta didik diberi ruang yang cukup untuk membuat diskresi (peluang untuk melakukan kesalahan, tanpa disengaja sebelumnya). Bila terjadi kesalahan diberi koreksi dan penjelasan tentang kesalahan tersebut. Proses pendidikan seperti ini akan menghasilkan out put didik yang percaya diri dan tidak tergantung kepada orang lain. Kemandirian justru harus diartikan sebagai kesediaan untuk bekerjasama dalam kelompok sehingga menghasilkan team work dari manusia manusia yang mandiri.

Integrasi tidak hanya pada muatan materi yang sifatnya teoritis kemudian digabungkan, tetapi juga menggabungkan berbagai aspek pendidikan lainnya. Integrasi tersebut meliputi integrasi secara utuh kemampuan belajar manusia yang dibedakan dalam tiga domain (ranah), yaitu ranah afektif, kognitif dan psikomotor. Juga mengintegrasikan teori, praktek dan penghayatan. Mengintegrasikan menejemen yang profesional dengan pengelolaan bernuansa spiritual, seperti keikhlasan, ketulusan dan kasih sayang. Termasuk di dalamnya adalah mengintegrasikan lingkungan sekolah dengan lingkungan masyarakat, khususnya pesantren yang sudah dikondisikan secara islami.

Dalam konsep pendidikan islam ada dua landasan utama yang menjadi dasar pijakan pengembangan pendidikan selanjutnya yaitu al- Qur'an dan alHadits sendiri. Sedangkan secara umum tujuan pelkasanaan pendidikan islam adalah: ${ }^{9}$

1. Mengenal Tuhannya (Allah SWT; disinilah urgensi tektualitas al-Qur'an dan al- Hadits sebagai landasan untuk mengenalkan Allah sebagai satusatunya Tuhan dan tanpa sekutu).

2. Mengenal hukum- hukumnya; mengenal hukum- hukumnya menemukan titik temunya dengan pembelajaran materi umum misalnya ilmu alam, biologi, sosial, politik, ekonomi, budaya, teknologi dan sebagainya yang hari ini banyak diminati manusia modern.

3. Mengenal cara belajar hidup yang benar sesuai dengan tuntutan dan tuntunan nilai- nilai yang telah diajarkan Allah dan rasulnya.

4. Mengenal dan belajar menyelesaikan masalah yang dimulai dari mengenali masalah kemudian mampu secara mandiri meyelesaikannya dengan baik, benar dan tepat. Dasar pendidikan yang dimaksud tidak

9 M. Fakhrur Rozy, "Pendidikan Agama Berbasis Integrasi", Skripsi UIN Malang, (Malang: Perpustakaan Pusat UIN Malang, 2007). 
lain ialah nilai-nilai tertinggi yang dijadikan pandangan hidup masyarakat atau bangsa tempat pendidikan itu dilaksanakan. Berkaitan dengan pendidikan Islam maka pandangan hidup yang didasari seluruh proses pendidikan Islam adalah pandangan hidup yang Islam yang merupakan nilai luhur yang bersifat trasenden, eternal, dan universal, dalam hal ini yang dijadikan landasan dalam pelaksanaan pendidikan Islam adalah Al-Qur'an, Sunnah nabi Muhammad, ijtihad, Almaslahatul Al-Mursalah, isttihsan, qias.

\section{Integrasi Pendidikan di MAN 3 Malang}

MAN 3 Malang secara berkesinambungan terus berpacu dalam peningkatan kualitas pelayanan dan pelaksanaan pendidikan untuk mengantarkan peserta didik mampu memiliki kemantapan aqidah, kekhusyukan ibadah, keluasan IPTEK, dan keluhuran akhlak, sehingga dapat berprestasi dalam rangka mengemban tugas sebagai pemimpin (kholifatullah) di muka bumi. Dalam rangka mewujudkan tujuan tersebut dan sejalan dengan program full day school, MAN MODEL Malang menyediakan kelas khusus Madrasah Aliyah Keagamaan Bertaraf Internasional (MAKBI) Berorientasi Timur Tengah. Keberadaan MABI tersebut sangat strategis bagi MAN 3 Malang sebagai jawaban atas masih banyaknya anggapan bahwa madrasah sebagai lembaga nomor dua yang tidak mampu bersaing dan berprestasi secara nasional, apalagi internasional. Dalam Menyelenggakan kegiatan-kegiatan nonakademik yang bertaraf internasional berorientasi Timur Tengah. ${ }^{10}$ Serta menyamakan (memu'adalahkan) ijazah Madrasah Aliyah Keagamaan Bertaraf Internasional (MAKBI) berorientasi Timur Tengah MAN 3 Malang dengan ijazah sederajat di Timur Tengah. ${ }^{11}$

Bangunan integrasi yang lebih menguatkan adalah adanya asrama atau ma'had al- Qalam, yang memberikan layanan belajar full day School, dengan berbagai kegiatan dan materi keagamaa yang meliputi Tajwid Zarkasyi, Arba'in Nawawi, Qowaidul Imla', Safinatun Najah, Taisiirul Khollaq, Fathul

10 Pembinaan siswa dalam ekskul ini dilaksanakan setiap hari di luar jam sekolah. Biasanya dimulai pukul 15.30 hingga pukul 17.00WIB. Pembinannya dari guru yang kompeten dan juga guru dari luar mAN 3 Malang yang profesional di bidangnya, sperti KIR, Pramuka, Paskibraka, PMR, Broadcasting, Master of Ceremony (MC), Kesenian ( Drama, Musik, Lukis, Puisi, Paduan Suara, Karawitan, Terbang Sholawat, dan Nasyid), Olah raga ( Futsal, Foot Ball, Volly Ball, Badminton, Table Tennis, Basket Ball, Taekwondo, dan Tapak suci), English Club, IT Club, Jurnalistic, Mekratonik Club, Olimpic Klub (Kimia, Fisika, Matematika, Komputer, Biologi, Bahasa Arab, Geografi, Hafidz).

${ }^{11}$ Wawacara dengan Uci Elly, tenaga pengajar di Man 3 Malang, tanggal 1 Juni 2013 dan informasi dari www.man3malang.com (diakses tanggal 13 Desember 2017) 
Qorib, Ta'limul Mutaalim, Bulughul Maram, kajian kitab-kitab klasik tersebut di klasifikasikan berdasarkan tingkatan dan kelas. ${ }^{12}$

\section{Integrasi Pendidikan di UIN MALIKI Malang}

UIN Maulana Malik Ibrahim Malang salah satunya lembaga pendidikan tinggi Islam yang menerapkan proses akademinknya memadu sains dan Agama. Dengan filosofis pohon keilmuan, Prof. Imam suprayogo membangun Struktur ilmu pengetahuan. ${ }^{13}$

Pada mulanya, ilmu pengetahuan hanya mempunyai tiga varian saja, yaitu: ilmu alam, ilmu sosial, ilmu humaniora. Umat Islam kemudian menambahkan satu varian lagi, yakni ilmu Agama Islam, dalam lembaga pendidikan dikenal dengan istilah ushuluddin, dakwah, syariah, adab dan tarbiyah. Dari sinilah sebenarnya yang memunculkan dikotomi dalam ilmu. Ada ilmu umum ada pula ilmu Agama. Ilmu umum masuk dalam wilayah Kementrian Pendidikan Nasional dan kebudayaan, sedangkan ilmu Agama masuk dalam garapan Kementrian Agama. ${ }^{14}$

Ilmu pengetahuan yang beraneka corak perlu dipetakan (concept map) terlebih dahulu, sesuai dengan disiplin jurusan dan program studi yang ada. Seperti, dalam konteks Fakultas Sains dan Teknologi UIN Malang, ilmu pengetahuan itu terbagi kepada beberapa Jurusan: Biologi, Matematika,

12 Wawacara dengan Uci Elly, tenaga pengajar di Man 3 Malang

13 Filosofis Sebuah pohon dimana pada sebuah pohon, terdapat akar, batang, dahan ranting, daun dan buah-buahan yang segar. Agar dahannya kuat maka pohon harus memiliki akar yang kokoh da kuat, begitu pula seterusnya dengan batang, ranting dan daun semua saling terkait satu sama lain supaya menghasilkan buah yang segar. Buah yang segar menggambarkan iman dan amal shalaih. Buah yang segar hanya akah muncul dari pohon yang memiliki akar yang kuat mecakar ke bumi, batang, dahan, dan dau yang lebat secara utuh. Buah yang segar tidak akan muncul dari akar dan pohon yang tidak memiliki dahan, ranting dan daun yang lebat. Demikiasn juga buah yang segar tidak akan muncul dari pohon yang hanya memiliki dahan, ranting, dan daun tanpa batang dan akar yang kokoh. Sebagai sebuah pohon yang diharapkan melahirkan buah yang segar, haruslah secara sempurna terdiri atas akar, batang, dahan, ranting, dan daun yang sehat dan segar pula. Tanpa itu semua mustahil pohon tersebut melahirkan buah. Demikian pula ilmu yang tidak utuh, yang hanya sepotong-sepotong akan seperti sebuah pohon yang tidak sempurna, ia tidak akan melahirkan buah yang diharapkan, yakni keshalihan individual dan keshalihan sosial. Selengkapnya lihat. Imam Suprayogo, Pendidikan Berparadigma Al-Quran Pergulatan Membangun Tradisi dan Aksi Pendidikan Islam (Malang: UIN Press, 2004), hlm. 51.

Saefuddin dkk, On Islamaic Civilization Menyalakan Kembali Lentera Peradaban Islam Yang Sempat Padam (Semarang: UNISSULA Press, 2010), hlm, 31932. 
Fisika, Kimia, Teknik Arsitektur, dan Teknik Informatika. Pada bagian ini mahasiswa berusaha diajak bertamasya bersama Alqur'an ke alam ilmu pengetahuan, dengan cara memetakan konsep dan mengklasifikasikan sains secara sistematis ke dalam berbagai disiplin Jurusan, atau tema-tema yang dikehendaki. Di sini, mahasiswa perlu diperkaya dengan konsep-konsep atau isyarat-isyarat sains yang bertaburan di dalam Alqur'an. Atau, dengan kata lain, mahasiswa disarankan terlebih dahulu "bersafari" melalui zikir dan pikir dengan menjelajahi semesta konsep atau tema sains yang ada di dalam Alqur'an. $^{15}$

Konsep atau tema sains yang bersendikan Alquran itu dipetakan sebagai berikut:

1. Bidang Biologi; sebagai suatu disiplin ilmu pengetahuan, biasanya berhubungan dengan analisis mengenai fenomena yang terdapat pada makhluk hidup, terutama mengenai asal-usul kehidupan. ${ }^{16}$

2. Bidang Matematika; sebagai disiplin ilmu pengetahuan, biasanya berkaitan dengan pengembangan pengetahuan tentang bilangan ('ilm al-'adad) dan ilmu hitung ('ilm al-hisab). ${ }^{17}$

15 Ahmad Barizi. Diakses dari http://blog.uin-malang.ac.id pada tanggal 11 Maret 2017 pukul 20.00

${ }^{16}$ Alqur'an menyebutkan: asal-usul kehidupan dari air (Qs. Al-Anbiyâ'/21: 30); tentang berbagai air sebagai sumber kehidupan (Qs. Thâhâ/20: 53, Qs. al-An'âm/6: 99, Qs. al-Nahl/16: 65, Qs. al-ㅌajj/22: 5); dunia tumbuhan dan tanaman yang tumbuh subur karena air (Qs. Fushshilât/41: 39, Qs. Qâf/50: 9-11, Qs. al-An'âm/6: 141, Qs. alNahll/16: 10-11); aneka ragam warna, buah, bunga, dan hasil panen yang dapat dipetik (Qs. al-iir/15: 19, Qs. al-Qamar/54: 49, Qs. al-Ra'd/13: 3-4, Qs. Thâhâ/20: 53, Qs. Luqmân/31: 10, Qs. al-ㅌajj/22: 5, Qs. al-Syu'arâ'/26: 7-8, Qs. al-An'âm/6: 95, Qs. Yâsîn/36: 36); gambaran dunia binatang dengan keanekaragaman, keindahan, dan daya tariknya yang menakjubkan (Qs. al-Najm/53: 45-46, Qs. al-Zukhruf/43: 12, Qs. al-An'âm/6: 38, 142-144, Qs. al-Nahl/16: 5-9), keberadaan komunitas binatang layaknya bangunan masyarakat manusia yang diorganisir secara apik (Qs. alAn'âm/6: 38), tingkah-laku binatang seperti lebah, laba-laba, semut, dan burung (Qs. al-Nahl/16: 66-69, 79, Qs. al-'Ankabût/29: 41, Qs. al-Naml/27: 18, Qs. al-Mulk/67: 19, dll); jenis-jenis tanah (Qs. al-A'râf/7: 58), dataran tinggi dan hujan lebat (Qs. alBaqarah/2: 265); masalah banjir (Qs. Saba'/34: 15-16), gerak hewan (Qs. al-Nûr/24: 45), ritus perkawinan tumbuhan dan hewan (Qs. Yâsîn/36: 36, Qs. al-Hijir/15: 22), bahasa percakapan seranggga (Qs. al-Naml/27: 15-22), dll.

17 Konsep pokok ilmu matematika adalah konsep Tawhîd, yaitu keesaan Allah (Qs. al-Ikhlâsh/112: 1). Penggunaan angka-angka dan bilangan-bilangan dalam Alqur'an digunakan dalam berbagai konteks (Qs. al-Kahfi/18: 11-12, 19, 22, Qs. alMu'minûn/23: 112-114, Qs. Ibrâhîm/14: 34, Qs. Maryam/19: 84, 94-95, Qs. alJinn/72: 24, 28, Qs. al-Taubah/9: 37, Qs. Hûd/11: 104, Qs. al-Muddatstsir/74: 31, Qs. Yûsuf/12: 20, dll), misalnya: dalam hubungannya dengan bentuk-bentuk peribadatan 
3. Bidang Fisika; Bila IPA (Ilmu Pengathuan Alam, natural science) diartikan sebagai ilmu yang memelajari susunan benda-benda dan perkembangannya, maka ilmu fisik (physical science, atau FISIKA) dimaknai sebagai ilmu yang menyelidiki fenomena-fenomena pada benda-benda tak bernyawa. Studi fisika, dalam konteks pemikiran Islam, dikenal dengan istilah Filsafat Alam. Ibn Sînâ (980-1037 M) membahas ilmu ini secara panjang lebar dalam Kitâb al-Syifâ' (Risalah Penyembuhan) dan Fann (Teknik Ilmiah). Tidak sedikit filosof dan sufi Muslim berjasa di bidang ini, seperti al-Kindî, Nâshir al-Dîn al-Thûsi, alBîrûnî, al-Baghdâdî, al-Ma'shûmî, al-Nazzâm, al-Baqillânî, Mulla Shadra, dan Sabziwârî, dan masih banyak yang lainnya. ${ }^{18}$

4. Bidang Kimia; Ilmu kimia bisa dibaca pada bahwa manusia dan lingkungan hidupnya terbentuk dari elemin-elemin dan substansi-

(Qs. al-Baqarah/2: 184-185, 203), dalam hubungannya dengan hukum perceraian (Qs. al-Thalâq/65: 1-2, 4, Qs. al-Ahzzâb/33: 49), dalam hubungannya dengan hukuman bagi orang-orang kafir (Qs. al-Baqarah/2: 80, Qs. Âli 'Imrân/3: 24, Qs. Hûd/11: 8), dalam hubungannya dengan jumlah saksi (Qs. al-Baqarah/2: 282, Qs. al-Thalâq/65: 2, al-Nisâ'/4: 15, Qs. al-Maidah/5: 106, Qs. al-Nûr/24: 4, 6-9, dan 13), dalam hubungannya dengan perjalanan matahari dan bulan (Qs. Yûnus/10: 5, Qs. alIsrâ'/17: 12, Qs. al-An'âm/6: 96) dalam hubungannya dengan penciptaan dunia (Qs. al-Baqarah/2: 29, Qs. al-Mu'minûn/23: 86, Qs. al-Thalâq/65: 12, Qs. al-A'râf/7: 54, Qs. Hûd/11: 7, Qs. al-Furqân/25: 59, Qs. al-Sajdah/32: 4, Qs. Qâf/50: 38, Qs. Nûh/71:

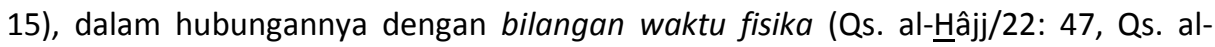
Sajdah/32: 5, Qs. al-Ma'ârij/70: 4), dalam hubungannya dengan pertambahan hasil panen (Qs. al-Baqarah/2: 261, Qs. Yûsuf/12: 43).

${ }^{18}$ Beberapa konsep fisika dalam Alqur'an terurai dalam berbagai tematik dan filosofi, seperti: dunia fisik alam (Qs. al-Nûr/24: 35); sifat cahaya (Qs. al-Furqân/25: 61, Qs. Yûnus/10: 5, Qs. Nûh/71: 16, Qs. al-Nûr/24: 13), fungsi cahaya (Qs. alHadîd/57: 13, Qs. al-Tahrîm/66: 8, Qs. al-Taubah/9: 32), makna spiritual dan fisikal cahaya (Qs. al-Baqarah/2: 17, 20), jarak dalam tahun cahaya (Qs. al-Sajdah/32: 5, Qs. al-Ma'ârij/70: 4, Qs. al-ㅂajj/22: 47), lamanya waktu dalam ruang alam semesta (Qs. Yûnus/10: 3, Qs. al-Sajdah/32: 4, Qs. al-Furqân/25: 59, Qs. Qâf/50: 38), energi panas (Qs. Yâsîn/36: 80, Qs. al-Wâqi'ah/56: 71-73, Qs. Thâhâ/20: 10, Qs. al-Naml/27: 7, Qs. al-Qashash/28: 29, Qs. al-Nahl/16: 81, Qs. Fâthir/35: 21), energi panas besi atau logam (Qs. al-Kahfi/18: 96, Qs. al-Ra'd/13: 17, Qs. al-Rahmân/55: 35, Qs. alZumar/39: 16), energi dan tenaga listrik (Qs. al-Baqarah/2: 19-20, Qs. al-Ra'd/13: 1213, Qs. al-Rûm/30: 24, Qs. al-Nûr/24: 43), neraca dan pengukuran dengan akurasi timbangan (kesetimbangan) dan ukuran (al-mîzân) (Qs. al-An'âm/6: 152, Qs. alA'râf/7: 85, Qs. Hûd/11: 84-85, Qs. al-Syûrâ/42: 17, Qs. al-Rahmân/55: 7-9), gelombang suara yang berada di atas ambang pendengaran manusia (Qs. alKahfi/18: 26, Qs. Saba'/34: 50), ruang atau kondisi nirberat (Qs. al-ㅂajj/22: 31, Qs. alAn'âm/6: 125), dunia warna (Qs. Fâthir/35: 27-28, Qs. al-An'âm/6: 99), dll. 
substansi yang tergabung menjadi sebuah "ikatan kimia" menurut hukum Allah. Manusia sendiri tercipta dari tanah liat, yang bisa dipastikan terjadi melalui proses kimia interaktif antara berbagai unsur dalam tanah yang bekerja menurut hukum-hukum Allah melalui proses perubahan dan kombinasi tertentu. ${ }^{19}$

5. Bidang Teknik Arsitektur; Seni arsitektur tidak saja bisa dilihat dari struktur dan susunan bangunan yang dihasilkannya, tetapi perlu dilihat dari perencanaan atau disainnya. Alqur'an memberikan ilustrasi gaya arsitektur ideal yang menawarkan kenyamanan, kesenangan, dan keindahan maksimal kepada pemakai/penghuninya, dan memerhatikan keseimbangan yang sempurna dengan lingkungan alam yang mengitarinya. ${ }^{20}$

6. Bidang Teknik Informatika; Sistem informasi dalam Islam meniscayakan keabsahan data yang disampaikan. Karena itu, disain

${ }^{19}$ konsep dan tema penciptaan telah menjadi tema sentral di dalam Alqur'an (Qs. al-An'âm/6: 2, Qs. al-Hijr/15: 26, Qs. Fâthir/35: 11, Qs. al-Rûm/30: 20, Qs. Hûd/11: 7, Qs. al-Anbiyâ'/21: 30, Qs. al-Dzâriyât/51: 49, Qs. Yâsîn/36: 36), penciptaan dari benda mati (Qs. al-An'âm/6: 95, Qs. Yûnus/10: 31), elemin dan reaksi kimiawi pada fenomena-fenomena alamiah batu-batuan dan sungai-sungai (Qs. alBaqarah/2: 74, Qs. al-A'râf/7: 58), struktur, sifat, dan kegunaan berbagai unsur kimiawi dalam madu (Qs. al-Nahl/16: 68-69). Selain itu, Alqur'an banyak menyebut tentang adanya emas dan perak sebagai logam mulia (Qs. Âli 'Imrân/3: 14, Qs. alTaubah/9: 34), sebagai hiasan dan barang mewah (Qs. al-Zukhruf/43: 33-53), sebagai tanda karunia Allah bagi penghuni surga (Qs. al-Hajj/22: 23, Qs. al-Kahfi/18: 3), masalah besi sebagai benda bermanfaat, benda keras, bahan konstruksi bangunan, baju besi/perang, dan alat penyiksa di neraka (Qs. al-Hadîd/57: 25, Qs. al-Isrâ'/17:

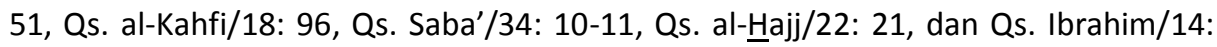
50), reaksi-reaksi exothermal dan endothermal dalam hubungannya dengan pemanasan benda tertentu yang dikemukakan dalam konteks hukuman neraka (Qs. al-Kahfi/18: 29, Qs. al-ㅌajj/22: 21, Qs. Ibrahim/14: 50, Qs. al-Dukhân/44: 45-46), benda-benda yang lebih kecil atau besar dari "atom" (Qs. al-Zalzalah/99: 7-8, Qs. Saba'/34: 22), dan lain-lain.

20 Seperti, gambaran rumah (hunian) yang dipadati kebun dan sungai yang mengalir (Qs. Âli 'Imrân/3: 198, Qs. al-Taubah/9: 72, Qs. al-Sajdah/32: 19, Qs. alNisâ'/4: 57, Qs. al-Ra'd/13: 35, Qs. al-Insân/76: 13-14, Qs. al-Musilât/77: 41-42), perumpamaan struktur bangunan rumah lebah (Qs. al-Nahl/16: 68-69), konstruksi bangunan yang memerlukan penguat dari besi (Qs. al-Hadîd/57: 25, Qs. al-Isrâ'/17: 51, Qs. al-Kahfi/18: 96, Qs. Saba'/34: 10-11, Qs. al-ㅌajj/22: 21, dan Qs. Ibrahim/14: 50), dan lain-lain. 
atau teknik informasi adalah suatu konsep untuk memermudah adanya akses dan proses informasi informasi. ${ }^{21}$

\section{Integrasi Pendidikan di UIN SYAHID Jakarta}

Sejak diresmikan sebagai UIN pada tahun 2002 UIN Jakarta memiliki agenda integrasi sains dan Islam yang tercantum dalam visi dan misinya. Visi yang ingin mewujudkan "sebuah lembaga yang terkemuka dalam mengembangkan dan mengintegrasikan aspek keislaman, keilmuan, kemanusiaan, dan keindonesiaan" didukung dengan misi yang jelas, disebutkan agenda integrasi:

1. Melakukan reintegrasi keilmuan pada tingkat epistemologi, ontologi, dan aksiologi, sehingga tidak ada lagi dikotomi antara ilmu-ilmu umum dan ilmu-ilmu agama.

2. Memberikan landasan moral terhadap pengembangan ilmu pengetahuan dan teknologi dan melakukan pencerahan dalam pembinaan iman dan takwa sehingga hal tersebut dapat sejalan.

3. Mengartikulasikan ajaran Islam secara ilmiah akademis ke dalam konteks kehidupan masyarakat, sehingga tidak ada lagi jarak antara nilai dan perspektif agama dan sofistikasi masyarakat.

Spirit integrasi ilmu pada visi dan misi tersebut dituangkan secara operasional dalam kebijakan kurikulum, mulai dari penyusunan silabus, perumusan pokok bahasan, sampai cara penyajian materi kuliah. Sebagai contoh kandungan isi seluruh mata kuliah dipandu dengan pola:

1. Mata kuliah keagamaan harus memuat: historical content ${ }^{22}$, theoritical content $^{23}$, practical content ${ }^{24}$, case content ${ }^{25}$, dan science and technology content. ${ }^{26}$

2. Mata kuliah umum harus memuat: historical content, theoritical content, practical content, case content, dan Islamic content. ${ }^{27}$

21 Alqur'an secara tegas menjelaskan pentingnya keabsahan data informasi (Qs. alHujurât/49: 6) dan untuk memermudah akses dan proses informasi (Qs. alBaqarah/2: 185, Qs. al-Thalâq/68: 7, Qs. al-Insyirâh/94: 5-6).

${ }^{22}$ Historical content adalah penjelasan sejarah lahir dan berkembangnya ilmu pengetahuan sampai saat ini

${ }^{23}$ Theoritical content adalah sajian serangkaian teori yang dikemukakan para ahli dari setiap periode

${ }^{24}$ Practical content adalah penjelasan manfaat ilmu untuk kehidupan

25 Case content adalah penjelasan kasus nyata yang relevan dengan materi kuliah.

26 Science and technology content adalah upaya untuk menjelaskan makna ayat al-Qur'an dan hadis dari segi sains dan teknologi untuk memperkuat keyakinan Islam dan mendorong pengembangan ilmu. 


\section{Analisis Penulis}

integrasi di lembaga pendidikan akan sangat terbentuk ketika lembaga mampu mensinergikan antara bangunan keilmuan yang berbasis pada ilmu pengetahuan sains (hal ini sudah di atur dalam Peraturan Diknas dan Depag) dan berlandaskan pada nilai-nilai syariat Islam yang telah di atur dalam Al Qur'an dan Hadits melalui hidden kurikulum atau real kurkulum. Lembaga pendidikan yang dirasa mampu mensinrgikan keduanya salah satunya adalah dengan adanya sarana prasarana yang mendukung seperti pondok pesantren yang memfasilitasi lembaga formal atau sekolah yang memfasilitasi ma'had/asrama.

Pesantren merupakan lembga pendidikan yang menerapkan bidang keilmuan agama secara utuh dan menyeluruh, dan tidak akan ada dikotomi ketika di interasikan dengan wawasan sains. Seperti SMA Nurul Jadid Probolinggo, lembaga pendidikan yang berada di bawah naungan Diknas ini juga bernaung dalam yayasan pesantren Nurul Jadid Probolinggo, sehingga kurikulum dari Diknas dan dari pesantren yang scenario pembelajarannya selama 24 jam mampu terintegrasi dengan baik. Selain itu, sekolah bersarama seperti MAN 3 Malang yang berada dibawah naungan Depag juga mampu menerapkan pembelajaran secara integrasi. Hal ini dikarenakan sekolah telah memfasilitasi asrama bagi siswa dengan serangkaian kegiatan yang berbasis agama di luar jam pelajaran sekolah secara kaffah.

Sebenarnya, dihilangkannya pendidikan dikotomian ilmu sudah terjawab sejak perubahan PTAI menjadi UIN dengan konsep yang ada pada UIN Malang maupun UIN Jakarta. UIN Malang lebih memilih pendekatan Imam Al-Ghazali yang mengklasifikasikan ilmu menjadi Fardlu 'ain dan fardlu Kifayah dengan metode "takwil" yang diambil dari ilmu-ilmu sosial. Budaya pendidikan yang dikembangkan disesuaikan dengan budaya universitas. Artinya semangat perubahan universitas diikuti juga dengan semangat pengembangan budaya yang berwawasan universitas juga baik yang ditunjukkan melalui riset-riset, publikasi hasil penelitian dan lain-lain. Dan sejauh ini UIN Maliki Malang sebagai pelopor pendirian ma'had atau asrama mahasiswa telah menjadi studi banding dari berbagai Perguruan Tinggi diberbagai kota, karena di pandang mampu mengembangkan budaya secara integrasi pula, yakni budaya kampus dan budaya peantren. Sementara UIN Jakarta dengan menggunakan paradigma integrasi ilmu dialogis dari lan G. Barbour yang memandang bahwa sumber ilmu yang dimiliki sains dan agama

27 Islamic content adalah prinsip dasar tauhid yang ditanamkan bahwa semua ilmu bersumber dari Allah. Sehingga ilmu umum dan agama tersebut merupakan sesuatu yang integral. Lihat. Asrori S. Karni, Etos Studi Kaum Santri Wajah Baru Pendidikan Islam (Bandung: Mizan, 2009), hlm. 309-31. 
sama-sama dianggap valid dan menjadi sumber koheren yang saling melengkapi. Bahkan, pemahaman tentang dunia yang diperoleh melalui sains diharapkan dapat memperkaya pemahaman keagamaan bagi orang yang beriman.

\section{Kesimpulan}

Integrasi memiliki arti penggabungan / pembauran hingga menjadi satu kesatuan yang utuh . menurut lan. G. Barbour, sebagai tokoh pengkaji hubungan sains dan agama telah memetakan hubungan antara keduanya. Pandangan ini memunculkan hubungan yang lebih bersahabat dari pandangan yang terdahulu. Yakni, doktrin yang dimiliki sains dan agama sama-sama dianggap valid dan menjadi sumber koheren dalam pandangan dunia. Bahkan, pemahaman tentang dunia yang diperoleh melalui sains diharapkan dapat memperkaya pemahaman keagamaan bagi orang yang beriman.

Model Integrasi Pendidikan Tradisional SKB tiga Menteri (P \& K, Dalam Negeri, dan Menteri Agama) yang menetapkan ketentuantentang kurikulum madrasah yang menyeimbangkan antara kurikulum umum dengan kurikulum agama (70\% : 30\%). Integrasi Pendidikan Modern SMA Nurul Jadid Probolinggo, dan MAN 3 Malang mampu menerapkan pembelajaran secara integrasi. Hal ini dikarenakan sekolah telah memfasilitasi asrama bagi siswa dengan serangkaian kegiatan yang berbasis agama di luar jam pelajaran sekolah secara kaffah. UIN Malang sebagai pelopor pendirian ma'had atau asrama mahasiswa Budaya pendidikan yang dikembangkan disesuaikan dengan budaya universitas.UIN Malang dan UIN Jakarta lebih memilih pendekatan Imam Al-Ghazali yang mengklasifikasikan ilmu menjadi Fardlu 'ain dan fardlu Kifayah dengan metode "takwil" yang diambil dari ilmu-ilmu sosial. Tetaapi UIN Jakarta berparadigma integrasi ilmu dialogis.

\section{Daftar Rujukan}

Barbour, Ian. G., Juru Bicara Tuhan Antara Sains dan Agama, Terj. E.R. Muhammad, Bandung; Mizan, 2004.

Barizi, Ahmad, http://blog.uin-malang.ac.id diakses tanggal 13 desember 2017.

Barizi, Ahmad, Pendidikan Integratif Akar Tradisi dan Integrasi Keilmuan Pendidikan Islam, Malang: UIN Maliki Press, 2011.

Haidar, Mengenai ordonansi guru Baca juga Nurhayati Jamas, Dinamika Pendidikan Islam di Indonesia Pasca Kemerdekaan, Jakarta : Rajawali Pers, 2008. 
http://www.anekamakalah.com/2012/12/integrasi-pendidikan-agama-danumum.html Diakses Tanggal 15 Desember 2017.

Karni, Asrori s., Etos Studi Kaum Santri Wajah Baru Pendidikan Islam, Bandung: Mizan, 2009.

M. Dahlan Dkk, Kamus Induk Istilah Ilmiah Seri Intelektual Surabaya; Target Press, 2003.

M. Fakhrur Rozy, "Pendidikan Agama Berbasis Integrasi", Skripsi UIN Malang, Malang: Perpustakaan Pusat UIN Malang, 2007.

Saefuddin dkk, On Islamaic Civilization Menyalakan Kembali Lentera Peradaban Islam Yang Sempat Padam, Semarang: UNISSULA Press, 2010.

Suprayogo, Imam, Pendidikan Berparadigma Al-Quran Pergulatan Membangun Tradisi dan Aksi Pendidikan Islam, Malang: UIN Press, 2004.

Wawacara dengan Uci Elly, tenaga pengajar di Man 3 Malang, tanggal 1 Juni 2013 dan informasi dari www.man3malang.com diakses tanggal 13 Maret 2017.

Tim Penyusun Buku, 2004 Memadu Sains dan Agama menuju Menuju Universitas Islam Masa Depan, Malang: Bayumedia, 2004.

Wawanara dengan Safitri Yuliana, alumni SMA Nurul Jadid tahun 2012. Diakses Tanggal 1 Maret 2017. 